\title{
A TRIBUTE TO PEDRO PAULO ABREU FUNARI
}

Lourdes M. G. Conde Feitosa ${ }^{1}$

In 1986 I had the pleasure of meeting professor Pedro Paulo Funari, year in which he started teaching in the course of History at UNESP, Assis, where I was a junior. In that moment I had already taken the courses on Ancient History I and II, but I enrolled for his extension courses on 'Archaeology' and 'Love and sexuality in classical antiquity'. The latter particularly inspired my choice for an academic career. With his coorientation in my Master's degree at Unesp and supervision in my Doctorate at Unicamp, I embraced the demanding but rewarding academic universe. We have worked together in several activities such as publications, lectures, courses, conferences, projects, and others. His intellectual quality is indisputable - as anyone can see from his curriculum since that very beginning - and his safe orientation was always very important to my intellectual development. But, what I would like to emphasize right now is his quality as a person.

Pedro Paulo Funari is a human being of captivating kindness and attention. As his student, the constant encouragement to scientific work and always to go a bit further had a special meaning on his statement "Count on me!", even after my doctorate had finished. As many colleagues in this Commemorative Edition agree, this welcoming attitude favored the formation of a "School" of Brazilian researchers in Ancient History, composed by dozens of students in Undergraduation, Master, and Doctorate courses and several partners in post-doctoral stages.

During my doctorate (1998 to 2002) I had the pleasure of sharing experiences with the colleagues Renata Garraffoni, Glaydson da Silva, Luciane de Omena, Dione bandeira, Nanci Oliveira, Cláudio Carlan, Marina Cavicchioli, Renato Pinto, Fábio Hering, Andrés Zarankin, Renata Belleboni. Team work resulted in publications and partnerships among us that highlight Funari's view of academic work: together we go further!

\footnotetext{
1 Assistant Professor, Sacred Heart University, Bauru, Brazil. E-mail: loufeitosa@uol.com.br
} 
The projection and relations established by Funari with numerous international scholars and his hard work in getting funds with funding agencies led to the arrival of numerous foreign professors at Unicamp, that strengthened contacts and productions and opened doors that encouraged his students to go to other lands. This way, I was welcomed by Professor José Remesal Rodríguez, at Barcelona University, in charge of CEIPAC (Centro para el Estudio de la Interdependencia en la Antigüedad Clásica), as part of my doctoral attributions, which was funded by Fapesp.

There I could work with Professor Remesal and other scholars of Ancient Rome as Antonio José Aguilera Martin, Victor Revilla Calvo, Luis Pons Pujol, Pablo Ozcáriz Gil, among others, who provided me with personal growth and learning as well as pleasant hours of coexistence and deeper knowledge on Spanish traditions. With Professor Remesal indications I continued my internship in Italy, in the Spanish, American, and French Schools of Rome, in the archaeological site of Pompeii and in the National Archaeological Museum of Naples. Such experiences were important in professional and personal terms for the development of my doctorate and future participation in international conferences and publications.

In this way, I thicken the voices of admiration for the professor and friend Funari, for his ability to convey knowledge, to stimulate and encourage the scientific production, for the example of commitment and loyalty. I express my gratitude for the opportunity to work and to partake with him, a constant source of inspiration. 